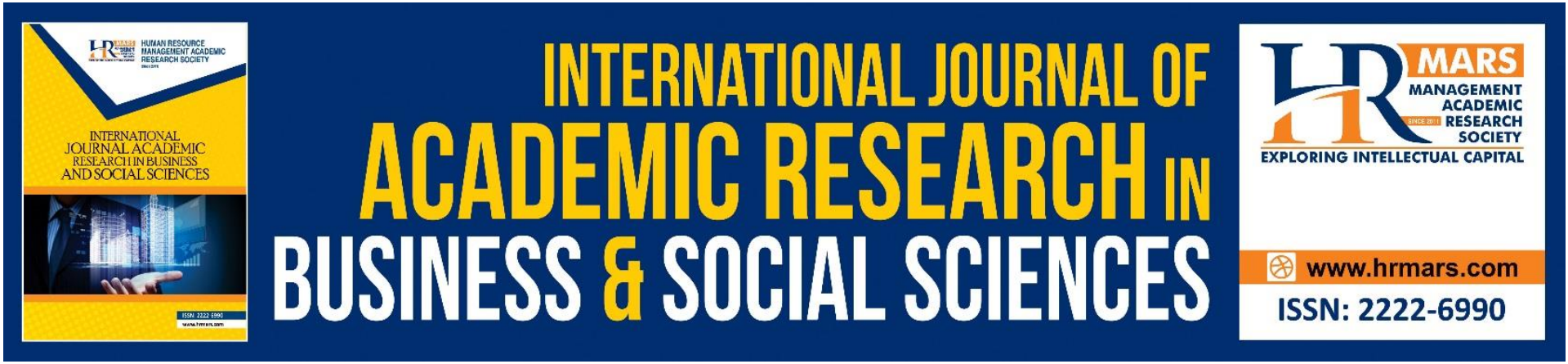

\title{
A Critical Evaluation of PEELI Project Run by the Punjab Government of Pakistan and British Council
}

Tehmina Mushtaq

To Link this Article: http://dx.doi.org/10.6007/IJARBSS/v11-i3/8656

DOI:10.6007/IJARBSS/v11-i3/8656

Received: 06 January 2021, Revised: 02 Febuary 2021, Accepted: 19 February 2021

Published Online: 17 March 2021

In-Text Citation: (Mushtaq, 2021)

To Cite this Article: Mushtaq, T. (2021). A Critical Evaluation of PEELI Project Run by the Punjab Government of Pakistan and British Council. International Journal of Academic Research in Business and Social Sciences, 11(3), 1080-1098.

Copyright: (c) 2021 The Author(s)

Published by Human Resource Management Academic Research Society (www.hrmars.com)

This article is published under the Creative Commons Attribution (CC BY 4.0) license. Anyone may reproduce, distribute, translate and create derivative works of this article (for both commercial and non-commercial purposes), subject to full attribution to the original publication and authors. The full terms of this license may be seen

at: http://creativecommons.org/licences/by/4.0/legalcode

Vol. 11, No. 3, 2021, Pg. 1080 - 1098

http://hrmars.com/index.php/pages/detail/IJARBSS

JOURNAL HOMEPAGE

Full Terms \& Conditions of access and use can be found at http://hrmars.com/index.php/pages/detail/publication-ethics 


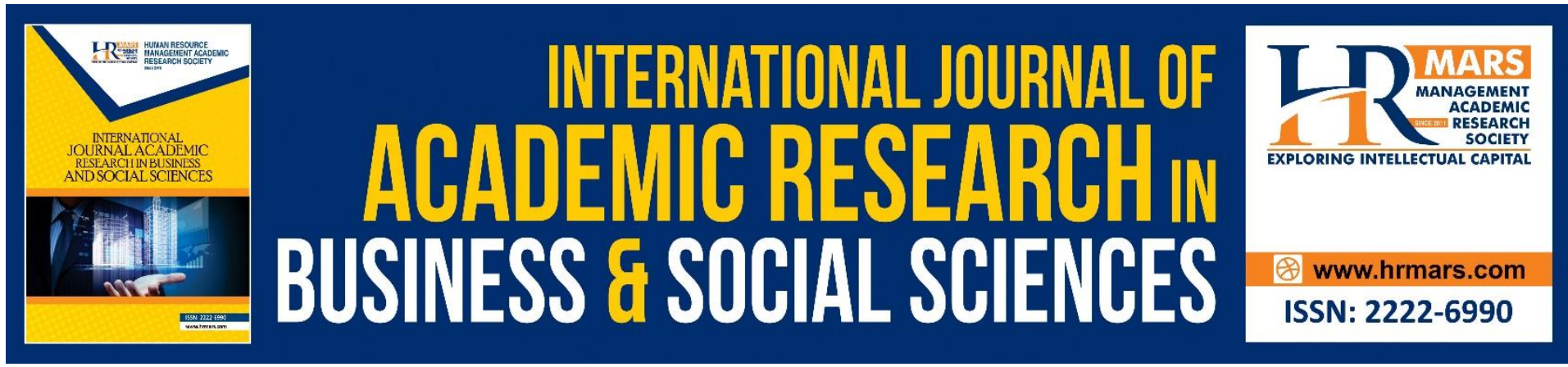

\title{
A Critical Evaluation of PEELI Project Run by the Punjab Government of Pakistan and British Council
}

\author{
Tehmina Mushtaq \\ Department of English, GIFT University, Gujranwala, Pakistan \\ Email: tehmninamushtaq164@gmail.com
}

\begin{abstract}
The quality of the infrastructure and educational system is epitome of every nation's economy, social integration and development. PEELI is a ray of hope from the slumbering system of education to receive first-class training to enhance the contents of teachers training, expand the quality of teacher's pedagogy, and instruction of use of English language in a classroom for better professional and academics hierarchy in primary level of education in Punjab. The quality of education builds and depends on the relevance, quality and rigor of available educational research. Moreover, medium of instruction and teacher training plays a pivotal role in any nation's educational system. It shows the academic progression of the teachers and learners. No one can deny the significance of English language and pedagogical skills in any educational institute. This study aims to emphasize and focus that all the skills of English language are equally important to turn the table in any educational system. This study aims the related training program such as PEELI (Punjab Educational English Language Initiative). It is an academic five years project of Punjab government in collaboration with British Council, which had started in 2013. The central objective of the study is to critically evaluate the effectiveness of the teacher-training program (PEELI) offered by British Council and Punjab government. However, this study followed mixed method research to conduct empirical and thematic analysis of the data. The findings have reported that proper training mechanism of teacher will ultimately upsurge their performance in educational context. While such performance is positively influenced by the PEELI initiative.
\end{abstract}

Keywords: Punjab Government, British Council, Teachers Training, PEELI, English Language, Education.

\section{Introduction}

Education helps in the development of any nation (Smith et al., 2017). It is as important to a person as a mother to a child. It leads to a promising and secure future and a stable life. It is the most important factor for all of us. It gives us power of perception to make a difference between right and wrong (Barrichello et al., 2020).

The primary school teachers of Punjab government like any other private school teachers have gone through this cascade training to teach the teachers' trainers for activity based lessons and active child-centered classrooms with polished and enhanced pedagogy skills 
with monolingual or bilingual based instructions to be carried out. PEELI has contributed to strengthen and polish Punjab government's teachers teaching skills to flourish the quality of instruction in a classroom which in turn will increase the student's learning outcomes.

As Nelson Mandela says, education is the most powerful weapon that can be used to change the world (Soudien, 2017). It plays a vital role in one's personal and social growth. Good education helps becoming good citizen, independent worker and to lead a better life. It gives us strength to solve any problem. It is the only basic way by which a desired change and raise in the society can be taken into effect.

This study will investigate the PEELI project and its implications on learning and teaching with regard to English language and pedagogical skills. This study will help to highlight the strengths and weaknesses of the project. It is always a controversy regarding medium of instruction in government schools across Pakistan (Nadeem et al., 2020). It pictures immense challenges to cater the global need to implement English language in an ordinary classroom of a government school in the Punjab province (Naz et al., 2020). An adequacy and shortfall of lacked training options and opportunities for teachers also poses a hindrance for better teaching (Rafique et al., 2018). Moreover, a delicate and fragile long-term framework for teacher development often becomes ambiguous. Thomas (2013) writes the same that effective role by teachers cannot be played unless they are given proper training.

The general purpose of the study is to discover the quality of the teacher training given in Punjab government primary and secondary schools by British Council in collaboration with Punjab government.

Besides, this research plans specifically to:

1. Explore the training which is, conducted under the banner of PEELI project.

2. Discover the good practices and challenges faced by teachers during the training.

3. Identify the strengths and weaknesses of the teachers during the training.

4. Justify the performance of the teachers who has or has not attended the training.

This study is based on the three main research questions which guide this study of learning and teaching process in relation to trainings in primary and secondary government schools in Pakistan, in reference to PEELI project.

1. How PEELI has been helpful to the teachers of Punjab government schools to improve English as a second language and teaching skills?

2. Has Punjab government schools have undergone the "CHANGE" since, it has been initiated and what input teachers have been contributing towards education since 2013?

3. Are the PEELI objectives, met since its initiative and is it being productive?

Since independence of Pakistan, eight education policies have been announced (Hameed-urRehman \& Sewani, 2013). Education is an integral part of developed nations and those societies who fail to recognize the importance of education can never stand and think on intellectual lines (Ahmad \& Yousaf, 2011). It is very sad to mention here that Pakistan is still striving to recognize the importance of education due to negligence in education policies (Zakaria et al., 2016). Although, seventy years, have been passed but we are still lagging behind in the field of education as none of the education policy has been truly implemented. Each policy is full of ambitions and a critic of previous failures and weaknesses.

Malik (2015) writes "The analysis of past policies shows most of them failed to achieve their goals". Even international funds are not helpful to bring a significant change in Pakistan's education field. All education policies more or less carried the same objectives but major change regarding teacher education came in the National Education Policy of 1992 . The 
further educational policies include National Education Conference 1947, National Commission on Education 1959, National Education Policy 1970, Education Policy 1972, National Education Policy 1979, National Education Policy 1992, and National Education Policy 1998-2010.

\section{Literature Review}

\section{The Status of English Language in Pakistan's Educational System}

English is the basic subject taught in almost all schools of the state of Pakistan (Manan et al., 2016). As, we all know the worth of this language, it is being the international language. It is an effectual way of communication among foreign allies. Teaching is an important job. It helps to build the nation through knowledge. A teacher is a facilitator, mediator and mentor (Warsi, 2004). He/she is a role model for her/his students

The linguistic map of Pakistan is quite complex with many languages; each of the four provinces has one or more dominant languages and a number of minority languages (Akram \& Mahmood, 2007). The emblematic status of English, due to its historical association with the elite and proto-elite (Hassan \& Ahmed, 2015, Rahman 1998), has helped in making it a prestigious language. English is the language of power in comparison with Urdu, the national language, and other regional languages of Pakistan (Ali et al., 2016).

Pakistan is a multilingual region. Its culture is rich with regional languages. However, Pakistan's national language is Urdu and official language is English (Akram \& Mahmood, 2007). Nevertheless, Pakistan being a colonized country, cannot deny the significance of English language. English language being a global language is a passport to work internationally and nationally with better perspectives. The unique status of English language in Pakistan is second to our state language, Urdu. We cannot deny its worthiness in our educational system.

A number of language policies have been, put forward by different ruling governments since the independence of our country (Haider \& Fung, 2019). But there has not been proper implementation of these policies regarding English language and pedagogical skills in education. Ciraso (2012) rightly identifies the difficulties and level of English language in Pakistan as compared to global standards.

Several researches done in Pakistan shows that those who are teaching English in schools may not have degree in the same subject (Fareed et al., 2018; Haider \& Fung, 2019). Teachers from different disciplines start teaching English as per criteria of hiring where the demand is to speak and understand English language. In many situations, teachers are given the responsibility of teaching English language in spite of the fact that they do not even truly know how to communicate in the said language, due to scarcity of English language teachers

\section{English Language Teaching (ELT)}

English Language is the official language in Pakistan and Urdu is the state language. English language, is being taught in all school levels of Pakistan. It is the medium of instruction generally from grade one onwards, and particularly from grade 6 onwards in Pakistan (Haider, 2018).

Private schools in Pakistan have become a symbol of class where medium of instruction is solely in English language. However, government schools, portray a totally different picture where medium of instruction is hardly English language but rather Urdu or local regional language is used for teaching (Mohammad et al., 2018). 
English language is a key to social, economic, education and tourism development. Nevertheless, Pakistan being a poor country, has a low literacy rate. Students find hindrance in speaking and communicating in English language. Moreover, development of teachers is also a major weakness in ELT. Teachers' professional development plays an important role in improving students' learning. According to a UNESCO report of 2009, there are 1,350,000 teachers working in government schools from primary to higher education which has tolled up to 1400000 as surveyed in 2016 (Rashid et al., 2017).

Another survey, conducted by Ammar et al., (2015) has shown that $58 \%$ government school teachers have no knowledge of the national curriculum while $73 \%$ have not been offered any courses on assessment techniques during their pre-service training

\section{Punjab Education English Language Initiative (PEELI)}

"Teacher" is the essence of quality education in Pakistan and in any part of the world. The number of teachers, in Pakistan is estimated at 1.35 million, working in public schools. Private and public sector organizations believe that education and training are vital to the development of a company, regardless of the nature or type of organization. (Saeed \& Zubair, 2019) defines, training and development as a process that uses diverse methods to enable new and old employees to communicate what they need to accomplish tasks. Training is also a powerful factor in promoting organizational expansion, skills development and improving profitability (Habib, 2013).

The Punjab Education and English Language Initiative (PEELI) is a training program for teachers to train elementary and middle school teachers of English medium instruction (EMI) in the Punjab province. The program aims to provide quality training to teachers and to help them better understand the content and provide them with tools to implement child-centered instruction with activity-based lessons which ultimately creates an environment conducive to learning (Bashir \& Batool, 2017).

Therefore, the British Council with the affiliation of Punjab government had launched the Punjab Education and English Language Initiative (PEELI) project in 2013. It was five years, project that should have been completed its cycle in 2018 however this project has been extended to 2020. This project plans to train 300,000 teachers across Punjab to improve their second language (English language) and teaching skills.

Sir Ciaran Devdne, the British Council chief executive in 2015 said, "British Council has several decades of hands-on experience and is globally recognized as leaders and experts in education and English Language" (Bashir \& Batool, 2017). Abdul Jabbar Shaheen, the Secretary for schools in Punjab, added, "The British Council has long been valueable friend and partner to us in our efforts and trials to bring world-class education to particularly Punjab and mainly to Pakistan and we welcome this new phase in our partnership as well" (Bashir \& Batool, 2017). The PEELI project main aim is to provide high quality education in English language to all the children who, are registered in primary and middle schools in Punjab province by 2018. However, the consequences show a different picture, at present.

Sobia Nusrat, Project Manager PEELI, British Council quotes, in her article, "We have huge challenges of monitoring and evaluating large scale teacher education projects like PEELI", that a limitation of resources affects PEELI activities as well since the impact of the training is only on a small group which is measured" (Nusrat, 2015). She further mentioned that PEELI's contribution and target, is based on the ambiguous and non-completed educational policies, the bias attitude of people and common individual towards English, the behavior of parents and teachers and the adverse educational policies of the government. 
The learners are in a habit of using their mother tongue, as they feel relaxed and satisfied, so in that way, they face a lot of obstacles and hurdles in learning English as a second language during their educational career. Khan and Khan (2016) have quoted that "syntactic errors in adult performance" occur due to the use of first or mother language in the life of a student and this impact remains for a long period in the mind of a learner.

The PEELI objectives are to:

1. Improve the ability of all primary teachers to be able to teach English as a foreign language.

2. Improve the English language skills of subject specialists of middle school teachers of English, Mathematics and Science.

3. Improve the classroom teaching skills of middle school subject specialists in English, Mathematics and Science to be able to teach through the medium of English.

\section{Training Evaluation Framework}

Teacher is the most critical and significant resource of any school. The efficiency and equity of school depends upon high-skilled, resourceful instructors (Imtiaz, 2014). However, if the training programs are to be evaluated at proper intervals it will help in the continuous improvement for the effectiveness of teaching in school.

\section{Models of Evaluation}

There are a number of evaluation models currently in use and practice. This study is going to give an overview of four evaluation models out which Kirkpatrick's model of evaluation, has been selected and used in this study.

1. Kirkpatrick's model of learning evaluation

2. Kaufman's model of learning model

3. Anderson's value of learning model

4. Brinkerhoff's method for learning evaluation

\section{Kirkpatrick's model of learning evaluation}

This model of evaluation has been in use for half a century now. Since then, two models have been out. A detailed description of both models, has been explained later (Reio et al., 2017). However, this model carries four levels.

a. Level 1-Reaction: It focuses on the training.

b. Level 2- Learning: It focuses on the learning.

c. Level 3 - Behavior: It focuses as how the training affected the work of the trainees in positive way.

d. Level 4 - Results: How the professional life of stakeholders has improved after the training?

\section{Kaufman's model of learning evaluation}

This, model has been built on reaction of the Kirkpatrick's model of evaluation (McKay et al., 2017). This, model is divided into five levels, which are as follows:

a. Level $1-$ Input and process

b. Level 2 and 3 - Micro levels (Acquisition and Application)

c. Level 4-Macro level (Organization Output)

d. Level 5-Mega level (Societal Outcomes) 


\section{Anderson's value of learning model}

This model suggests to focus between the programs' goals and strategic priorities of the organization (Pérez-Ordás et al., 2021). Only aligned goals help to evaluate success in the learning program. This model has three-staged cycle, which is as follows:

a. Stage 1 - Current alignment of goals against organization's priorities.

b. Stage 2 - Use a range of methods to evaluate the learning.

c. Stage 3 - Establish a most relevant approach to measure the learning of your organization.

\section{Brinkerhoff's method for learning evaluation}

It involves in identifying most and least successful cases within our learning program and analyzing them in detail (Hooshyar et al., 2019). With the help of the comparison of the two, it assists in our future endeavors. It helps us to dig deeper, learn and shout about success.

This paper presents Kirkpatrick's model of evaluation for teachers training. The old and new, both models are being, discussed here. However, the latest and new model is used for the analysis of the data.

\section{Kirkpatrick's Model of evaluation}

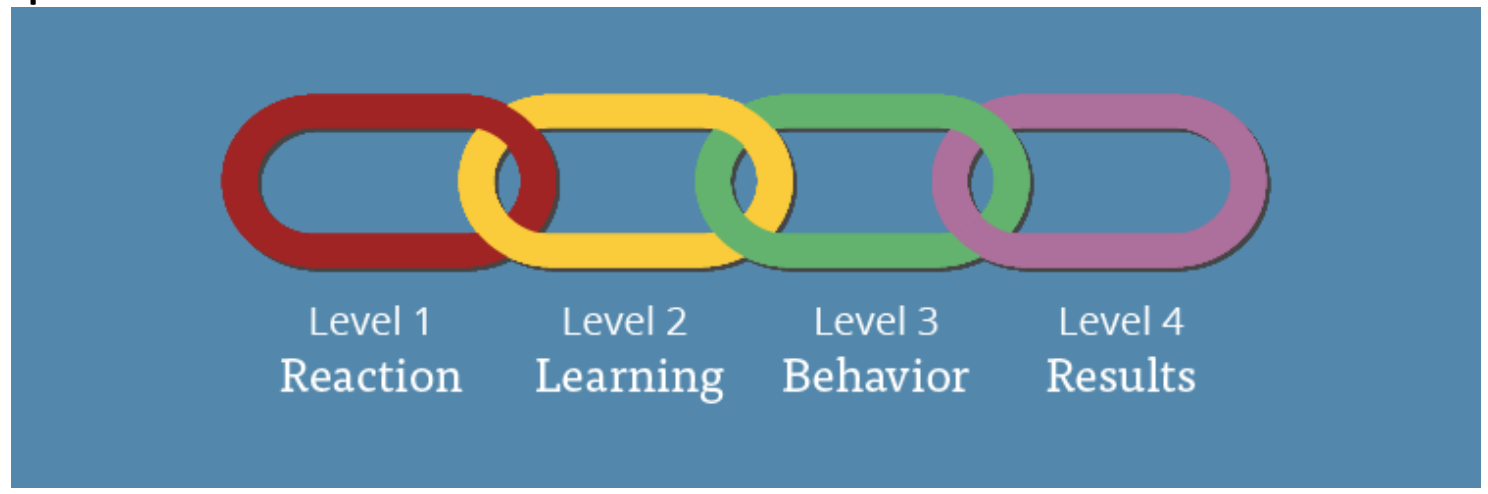

Figure 1

Donald Kirkpatrick in mid-50s developed a four-level model to be used primarily to evaluate training. It is, also called four levels of learning evaluation model. It has been declared as the best-known model for evaluating and analyzing the results of training and educational programs. Any style of training, can be evaluated based on four levels criteria. Although La Duke (2017) failed to provide evidence for the embedded chain with Kirkpatrick's original model, the four levels of evaluation are as under:

\section{Level 1: Reaction}

It measures the satisfaction of trainees.

\section{Level 2: Learning}

It assesses if they had understood the training objectives and if they have increased their experience, knowledge and skills.

\section{Level 3: Behavior}

It analyzes if they are implementing their knowledge of what they have learned during the training in their schools. Teevno (2011), observed that levels 3 and 4 are very hard to evaluate. 


\section{Level 4: Results}

It determines how the training had put a positive impact on the organization and over all what are the objectives of the training have been achieved.

The evaluation based on this model needs to start from level 1 to 4 . Data collected at each level can be used as a building block or foundation for the following levels analysis. The abovementioned model has undergone major change since its development.

The four levels of Kirkpatrick are the best in assessing the effectiveness of training. These levels are sequential and comprehensive, far beyond "jokes," becoming actual learning, behavioral changes, and including long-term actual results including assessment models!

Showing that the value of training begins before the program even starts. The late Dr. Donald L. Kirkpatrick said:

The trainers must identify the attitudes, knowledge and skills necessary to achieve the desired behavior (behaviors). The last challenge is to provide the training program in a way that enables participants not only to know what they need to know but also to respond in a positive way to the program.

La Duke (2017) argued to improve the old Kirkpatrick's model of evaluation. However, Teevno (2011) had analyzed that the old model failed to signify the education programs and its work out.

\section{New World Kirkpatrick's Model}

A new and developed model called New World Kirkpatrick's model has been introduced by Kirkpatrick partners, Sir. Donald's son and daughter in law, Jim and Wendy Kirkpatrick in 2010. It has added new elements and dimensions to help people and operationalize the evaluation effectively.

It begins with level 4 and works upside down. Levels 1 and 2 of the new models provides data related to effective training whereas level 3 and 4 provides the needed data related to the training effectives.

\section{THE NEW WORLD KIRKPATRICK MODEL}

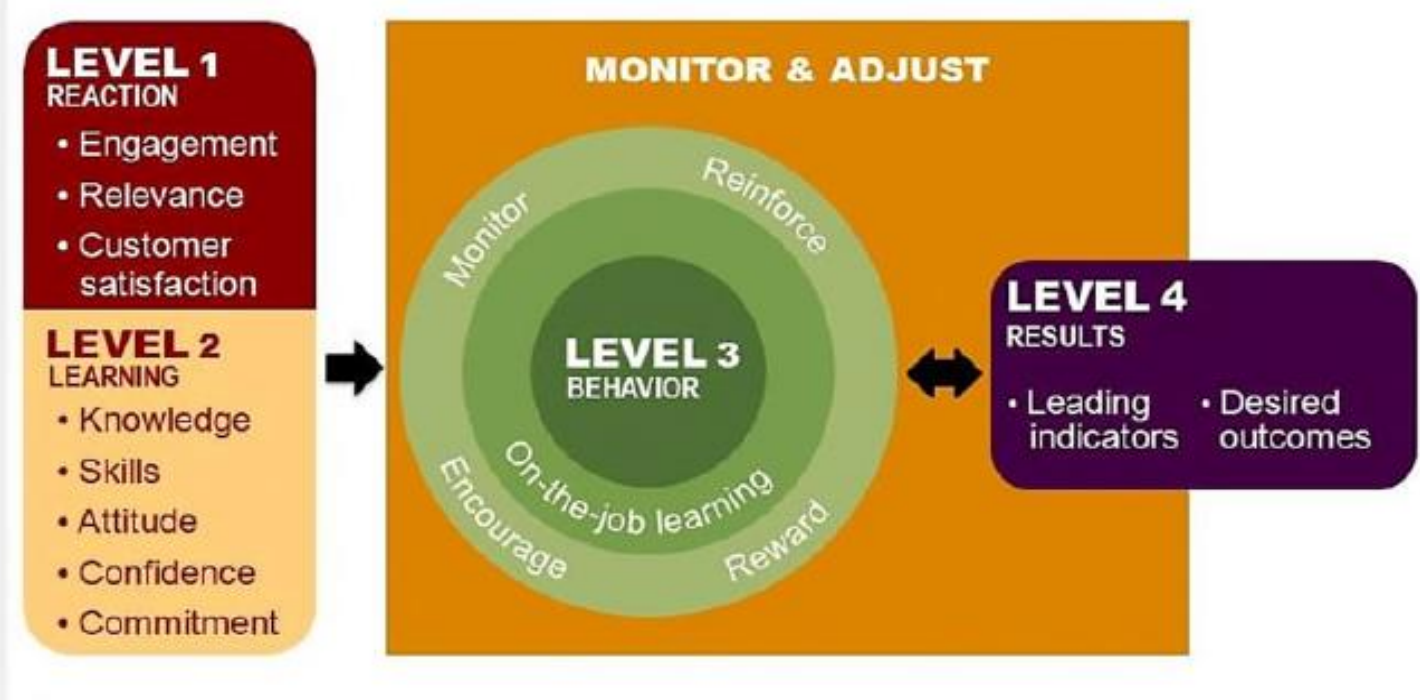

Figure 2 


\section{Level 4: Results}

It shows the combination of the projects purpose and objectives accomplished. It identifies positive answers to the question "what did this project deliver and contribute?" Few indicators, have been introduced to contribute to the success of the organization and projects related to it. The leading indicators include:
a. Learner's satisfaction
b. Employee's engagement
c. Cost containment
d. Quality

These indicators are in balance with a focus on the highest level, results. For example, an educational organization with excellent learner's satisfaction may go out of balance if it does not maintain quality education (Barash et al., 2020). Only if the organization comply rules and regulations, it can keep students and parents happy and satisfied.

\section{Level 3: Behavior}

It shows how the teachers implement the information and knowledge that they have gained during the training. The indicators related to this level are:

a. Critical behaviors

b. Required drivers

c. On-the-job learning

Critical behaviors depend upon how an employee behaves and performs on the job after the training. Such behaviors are the most important for achieving organizational goals. Required drivers includes the drivers that review or reinforce, monitor, encourage and reward performance of critical behaviors on the job. Examples may be aids, coaching, work review or recognition for excellent or outstanding job (La Duke, 2017). These drivers are the key to accomplish desired on-the-job application of what is learned. Organizations that reinforce or review the skills and knowledge learned during training can expect as much as $85 \%$ application on the job. On-the-job learning is related to two important facts of modern work organizations.

I. Around $70 \%$ learning takes place on the job.

II. Motivation and personal responsibility are partners to review and reinforce efforts for desirable performance.

\section{Level 2: Learning}

It is the degree to which participants develop the prospective added. The drivers for level 2 are:
a. Knowledge and Skill
b. Attitude
c. Confidence
d. Commitment

Knowledge is what we know and skill is what we can perform or do. Often organizations ignore the fact of lack of motivation and diagnose poor performance of teachers by mistakenly thinking that it is due to lack of knowledge and skill.

Attitude perceives how training participants believes to implement what is learned by them (La Duke, 2017). Confidence is the level to which the participants of training think that they have learned during the training. Commitment is related to the motivation to apply expertise and capability learned during training to their jobs on daily basis. 


\section{Level 1: Reaction}

It is the degree to which participants absorb the knowledge given to them at the learning event. It has 3 dimensions;
a. Satisfaction
b. Engagement
c. Relevance

Satisfaction refers to participant's satisfaction throughout the training. Engagement relates to the degree to which participants are actively engaged and giving to learning experience. Personal responsibility and program interests are directly related to the measurement of the engagement. Relevance depends upon the training participants to apply the content of their training on the job (Barash et al., 2017).

In general, we can say that we can begin to evaluate a project by observing leading indicators and determine how to contribute to achieving the fourth level. Then decide what you can do to get good results (level 3). What is required for good training of staff (Level 2)? Last but not least, what type of training will be the product of efficient transfer of skills (Level 1)?

\section{Methodology}

\section{Research Design and Process}

A research design illustrates the method of conducting a study (Bell et al., 2018). For instance, when a study collects a data at single time and present findings based on analysis, it refers to cross-sectional design (Buckley et al., 2017). In contrast, when a study collect data at two different time durations to explore pattern in respondent's behavior, it refers to longitudinal design (Bloomfield \& Fisher, 2019). In this regard, the current study is following crosssectional design.

The foundations of the study are based on existing theories and literature. It ultimately implies to the deductive reasoning (Armat et al., 2018). Similarly, as data have been collected from quantitative and qualitative perspective; therefore, this study is following mixed method approach to present findings of the study.

\section{Data Collection Process}

This study has followed a mixed method approach; therefore, data is related to qualitative and quantitative perspective. The quantitative data have been collected by disbursing the survey questionnaire comprising 22 questions. However, 95 teachers attending PEELI trainings responded to the questionnaire which is then used in SPSS to analyze the collected data.

The six interviewers are selected after their consent who volunteered to share their experiences, experienced during PEELI training after sharing objectives with them. This study has sent emails to several master trainers out of which six trainers, responded to email and have shown willingness to participate and gave interview for this study. The interviews were conducted between August and October 2020. The participants are both male and female teachers that belonged to different cities, have varied academic fields and qualifications. The interview comprises of fifteen open-ended questions

\section{Data Analysis}

\section{Qualitative Data Analysis}

Thematic analysis was done to examine the data. According to Bashiruddin and Qayyum (2014), "the qualitative data is analyzed by managing and reducing data into comprehensive 
themes and forms which connect the data". La Duke (2017) pinned down that the process of data reduction into intelligible forms in such a way that the quality of the data is not compromised. So according to that, the data was arranged into different categories and codes to generate new ideas from the data. The codes were later simplified and interconnected to produce important characteristics of the data.

Finally, these categories were presented by applying new world's Kirkpatrick's model of evaluation. The training pursued the trainee to inculcate their learning into their teaching for PEELI has left a positive mark on the trainees. The teachers training in general and PEELI training in particular helped teachers to develop good language skills particularly speaking and listening skills, excellent pedagogical expertise, to groom their students and themselves for a brighter future.

As the new world Kirkpatrick's model of evaluation suggests, the trainees of the project are in compliance with the model. The hierarchy of the model suggests the following detail: -

\section{Level 4: Results}

The trainee satisfaction over the project shows that the objectives of the training have been achieved. The learner (teachers) had been confident in speaking English language during the workshop, polish their language skills and later on their job. It also shows that quality of the training modules is in compliance with the learners and it gives them confident to make use of the product into their classroom. Activity based learning is a new phenomenon in Pakistani government schools where in presence of limited resources, teachers engage students in activity-based learning.

\section{Level 3: Behavior}

The teachers are confident to apply their skills on their job and with their co-teachers. The teachers can plan and organize in-campus training for other fellow teachers. This way the cycle of learning continues. The required drivers for learning behavior are reinforce or review, monitor, encourage and reward. The key to success is achieved when the teachers are satisfied and apply what they have learned on their job

\section{Level 2: Learning}

The level two comprises of the standards of knowledge and skills, attitude, confident, and commitment. The interview shows that participants of the training are confident that they have several skills during the training including time management, language and pedagogical skills and so on. The less teaching time and student-centered class is the essence of the learning and product of the PEELI project.

\section{Level 1: Reaction}

The level to which participants react to the learning includes following dimensions
a. Satisfaction
b. Engagement
c. Relevance

The participants showed pure satisfaction over the workshop. They had enjoyed the training and learning sessions a lot. They were eager to apply the concepts and activities learned at the training, in their schools, on their jobs. 


\section{Quantitative Data Analysis}

The data obtained from the questionnaires was entered into SPSS 21.0 for windows. The analysis took place using its statistical tools. Descriptive statistics and reliability analysis is measured in addition to the mean value of the coefficient.

The quantitative analysis is based on the following three objectives;

1. Improve the ability of all primary teachers to be able to teach English as a foreign language.

2. Improve the English language skills of subject specialists of middle school teachers of English, Math and Science.

3. Improve the classroom teaching skills of middle school subject specialists in English, Math and Sciences to be able to teach through the medium of English.

\section{Reliability Analysis}

Cronbach's alpha intends to measure internal consistency of items in the questionnaire. It varies between zero and one. If the alpha is closer to one, the internal consistency of the items is greater in the questionnaire. Total number of questions or items in the questionnaire are 22 and using five level Likert scale. Hence " $N$ " of items in the mentioned Cronbach alpha's test is 22 .

The following table indicating the reliability values of each objectives. The threshold or minimum acceptable value of Cronbach alpha is 0.7 (Souza et al., 2017), while the Cronbach alpha of each objective is greater than threshold level.

Table 1: Reliability

\begin{tabular}{|l|l|l|}
\hline & Cronbach's alpha & Cronbach's alpha based on standardized items \\
\hline Objective \# 1: & .942 & .944 \\
\hline Objective \# 2: & .945 & .946 \\
\hline Objective \# 3: & .965 & .965 \\
\hline
\end{tabular}


INTERNATIONAL JOURNAL OF ACADEMIC RESEARCH IN BUSINESS AND SOCIAL SCIENCES

Vol. 11, No. 3, 2021, E-ISSN: 2222-6990 @ 2021 HRMARS

\section{Mean Comparison of Variables}

Table 2: Comparison of Mean value and standard deviation of three objectives of PEELI training

\begin{tabular}{|c|c|c|c|c|c|c|c|}
\hline $\mathrm{Sr}$ & Variables & Objectiv & $\# 1$ & Objecti & $\# 2$ & Object & \# 3 \\
\hline & & Mean & Std. D. & Mean & Std. D. & Mean & Std. D. \\
\hline 1 & $\begin{array}{l}\text { Reading skill have been } \\
\text { improved due to } \\
\text { various activities. }\end{array}$ & 3.5368 & 1.303 & 3.54 & 1.302 & 3.315 & 1.354 \\
\hline 2 & $\begin{array}{l}\text { It has improved my } \\
\text { writing skills in a } \\
\text { constructive way. }\end{array}$ & 3.7368 & 1.064 & 3.673 & 1.03597 & 3.642 & 1.147 \\
\hline 3 & $\begin{array}{l}\text { The trainer had } \\
\text { emphasized on } \\
\text { listening skills as well. }\end{array}$ & 3.7895 & 1.156 & 3.747 & 1.13895 & 3.800 & 1.077 \\
\hline 4 & $\begin{array}{l}\text { I was fully engaged } \\
\text { during the workshop. }\end{array}$ & 3.9263 & 1.013 & 3.936 & .98726 & 3.873 & 1.074 \\
\hline 5 & $\begin{array}{l}\text { I am happy to be part } \\
\text { of this training. }\end{array}$ & 3.9684 & 1.076 & 3.989 & 1.14385 & 3.884 & 1.219 \\
\hline 6 & $\begin{array}{l}\text { My professional } \\
\text { behavior towards my } \\
\text { job has been changed. }\end{array}$ & 3.8526 & 1.061 & 3.989 & 1.04672 & 3.810 & $\begin{array}{l}1.0241 \\
2\end{array}$ \\
\hline 7 & $\begin{array}{l}\text { My learning skills are } \\
\text { continuously } \\
\text { reinforced and } \\
\text { reviewed }\end{array}$ & 3.8211 & .999 & 3.810 & 1.11369 & 3.800 & $\begin{array}{l}1.1260 \\
9\end{array}$ \\
\hline 8 & $\begin{array}{l}\text { My educational } \\
\text { organization has } \\
\text { rewarded me for } \\
\text { better performance. }\end{array}$ & 3.2526 & 1.237 & 3.473 & 1.14708 & 3.600 & $\begin{array}{l}1.2749 \\
6\end{array}$ \\
\hline 9 & $\begin{array}{l}\text { I am feeling } \\
\text { encouraged after } \\
\text { attending the training. }\end{array}$ & 3.7474 & 1.110 & 3.757 & 1.18246 & 3.536 & $\begin{array}{l}1.3433 \\
1\end{array}$ \\
\hline 10 & $\begin{array}{l}\text { As a PEELI trainee, I } \\
\text { feel responsible to } \\
\text { motivate others to } \\
\text { perform well. }\end{array}$ & 3.9789 & .999 & 3.768 & 1.14346 & 3.578 & $\begin{array}{l}1.1538 \\
9\end{array}$ \\
\hline 11 & $\begin{array}{l}\text { I am going to } \\
\text { implement what I } \\
\text { have learned. }\end{array}$ & 3.9579 & 1.1100 & 3.926 & 1.01313 & 3.726 & $\begin{array}{l}1.1889 \\
8\end{array}$ \\
\hline 12 & $\begin{array}{l}\text { My pedagogical skills } \\
\text { have been improved. }\end{array}$ & 4.0000 & .96756 & 3.852 & 1.05153 & 3.768 & $\begin{array}{l}1.0664 \\
4\end{array}$ \\
\hline 13 & $\begin{array}{l}\text { I have gained } \\
\text { confidence after the } \\
\text { training. }\end{array}$ & 3.8947 & 1.086 & 3.863 & 1.09749 & 3.873 & $\begin{array}{l}1.1227 \\
1\end{array}$ \\
\hline 14 & $\begin{array}{l}\text { My language skills } \\
\text { have been reinforced }\end{array}$ & 4.0737 & 1.013 & 3.863 & 1.04790 & 3.863 & $\begin{array}{l}1.0877 \\
5\end{array}$ \\
\hline
\end{tabular}


INTERNATIONAL JOURNAL OF ACADEMIC RESEARCH IN BUSINESS AND SOCIAL SCIENCES

Vol. 11, No. 3, 2021, E-ISSN: 2222-6990 @ 2021 HRMARS

\begin{tabular}{|l|l|l|l|l|l|l|l|}
\hline & $\begin{array}{l}\text { and I have gained a lot } \\
\text { of knowledge. }\end{array}$ & & & & & & \\
\hline 15 & $\begin{array}{l}\text { I am satisfied of what I } \\
\text { have learned. }\end{array}$ & 4.0000 & 1.000 & 3.800 & 1.07782 & 3.852 & $\begin{array}{l}1.1295 \\
7\end{array}$ \\
\hline 16 & $\begin{array}{l}\text { The training will help } \\
\text { me in my teaching. }\end{array}$ & 4.0737 & 1.033 & 3.915 & 1.19095 & 3.915 & $\begin{array}{l}1.0784 \\
5\end{array}$ \\
\hline 17 & $\begin{array}{l}\text { I was actively involved } \\
\text { in the training. }\end{array}$ & 4.0421 & .988 & 3.957 & 1.04082 & 3.894 & $\begin{array}{l}1.1712 \\
3\end{array}$ \\
\hline 18 & $\begin{array}{l}\text { I always apply the } \\
\text { content of the training } \\
\text { on the job. }\end{array}$ & 4.0000 & .967 & 4.000 & .98930 & 3.894 & $\begin{array}{l}1.0961 \\
6\end{array}$ \\
\hline 19 & $\begin{array}{l}\text { The trainer was } \\
\text { responsive and } \\
\text { knowledgeable. }\end{array}$ & 4.0526 & 1.014 & 3.989 & .98386 & 3.778 & $\begin{array}{l}1.1315 \\
5\end{array}$ \\
\hline $\begin{array}{l}\text { The training has } \\
\text { assisted me in } \\
\text { teaching. }\end{array}$ & 4.1053 & .950 & 3.989 & .98386 & 3.821 & $\begin{array}{l}1.1390 \\
5\end{array}$ \\
\hline 21 & $\begin{array}{l}\text { The training met my } \\
\text { needs. }\end{array}$ & 3.8316 & .996 & 3.736 & 1.15049 & 3.757 & $\begin{array}{l}1.0887 \\
8\end{array}$ \\
\hline 22 & $\begin{array}{l}\text { I would recommend } \\
\text { this training to my } \\
\text { colleagues. }\end{array}$ & 3.9053 & .979 & 3.957 & 1.06107 & 3.757 & $\begin{array}{l}1.0690 \\
6\end{array}$ \\
\hline
\end{tabular}

\section{Relationship between Coefficients}

As mentioned earlier, this helped me to analyze and understand the strength of the linear relationship existing among twenty-two variables.

Analysis of the data of all three objectives shows that most of the variables, are correlated with each other. The details of relationship between coefficients for the three objectives are as under:

\section{Objective One}

First correlation, is observed between reading and writing skills. The coefficient for these two variables is 0.755 . It means that reading skills helped in improving writing skills and has linear bonding between each other. Second linear relation is observed between pedagogical skills which have been improved as the teachers were fully engaged during the training. The degree of statistical relationship is 0.782 . As we know the larger the number, the stronger will be the relationship during the training. Third relationship is observed that due to responsive trainer, the content learned on the training assisted the teacher and thus have a linear association carrying the value of 0.745 . The next kinship is observed that the teachers were happy and satisfied after attending the training and are therefore confident about recommending it to others and has a coefficient value of 0.666. Furthermore, it also shows association between the variables of, recommending the training to the other colleagues as it met the trainees needs and has the value of 0.670 .

\section{Objective Two}

The second objective also shows linear relationship between its variables. Listening and reading skills are again related to each other and has coefficient of 0.646 . It further shows a 
linear connection between language skills being improved and thus teachers were satisfied of what they have learned and its value is 0.673 . It also shows that language skills have been improved. The teachers were actively involved during the training has strong relationship with the language skills being polished and has coefficient value of 0.741 . The teachers feel encouraged after the training as their reading skills have been improved due to various activities, it carries the value of 0.612 . Last but not least, the trainer had emphasized on listening skills and teachers' reading skills have also been improved. It shows the value of 0.646 .

\section{Objective Three}

The third objective has almost the same relationships between its variables. Firstly, the teachers are going to implement the content that they have learned during the training as their reading skills have been improved and carries the value of 0.622 . With the value of 0.621 the trainers have emphasized on the listening skills as their writing skills also have improved. With the degree of 0.712 , the teachers were happy to be part of the training as they were fully engaged. With the value of 0.606 , the PEELI trainees feel responsible to motivate others to perform as well and would recommend the training to other colleagues as well

\section{Discussion}

\section{Qualitative Data Interpretation}

The qualitative data analysis shows that structured interview questions are formed. Six head teachers showed consent to give interview through email. To get fair result, numerous teachers from different cities were contacted however, only six head teachers agreed to give interview. All the teachers have $5+$ years teaching experience. They all have attended at least one phase of the PEELI training. Keeping in view the background of English language for most of the teachers the master trainers used clear, simple and easy language to coordinate with each other.

The main outcome of the training is to improve their second language (L2) and be fluent. The teaching style also attracted the trainees where the teaching environment was entirely English speaking and $\mathrm{A} / \mathrm{V}$ aids were used during the training to make it more effective and student-centered. A number of other outcomes to mention are using questioning techniques, giving effective feedback and clear instructions in a classroom.

PEELI training has put a positive impact on teachers teaching methodologies in the classroom. More focus is given to less teachers talk time, available resources inside the classroom are used as A/V aids, stress on language skills and time management is also given.

The teachers were able to inculcate the contents learned during the training in their classrooms. The strength of this training comprises of using government textbooks during the training. British Council master trainers are the major attraction of the training. It provides interactive learning environment and main focus on all four language skills. The main weaknesses of the training is that there is poor or no coordination between the trainers and trainees during or after the training, the training days are found less by the trainees and there is no proper check or feedback taken after the training. Furthermore, certification or some incentive from the organization or the training platform gives more spark to the trainees in the positive way. 


\section{Quantitative Data Interpretation}

The quantitative data is analyzed through SPSS (version 21.0). The Cronbach alpha's value, shows that all the variables, in the questionnaire are closely related to each other. The high value in this study shows that the whole study is dimensional in nature. The variables have high consistency and is acceptable for this research.

Most variables, in the questionnaires are related to each other which shows that they are dependent on each other. The descriptive statistics of overall mean value shows that the trainees are very enthusiastic and mostly have accorded to the questions asked in the questionnaire. They have agreed that this training assisted them to improve their all-language skills i.e., reading, writing, listening and speaking skills in true means which is the main reason behind the whole project of PEELI.

The trainers were very cooperative during the training. They are master trainers and have full command over their respective mediums. This training has helped them to improve their language skills particularly speaking and teaching skills. This training is based on ABLE Activity based learning in English. By the end of their respective tenure of the workshop, the learner reflects his/her learning, identify areas for further improvement by making an action plan.

\section{Recommendations}

At the end, following recommendations are being jotted down for further upcoming educational trainings to avoid further loopholes. They are as under: -

\section{Reward}

Reward is a part of any learning and compel a learner to do better (Karim et al., 2019). If PEELI phases includes certificates at the end of each module it will enhance the participant's motivation on to higher level. Thus, awarding certificates from the organization or British Council will follow greater enthusiasm on the part of stakeholder.

\section{Proper follow-up}

There should be a proper follow-up of training conducted further in the respective schools. It will ensure the execution and implementation of acquired learning to benefit the child, truly.

\section{Duration of phases}

One phases of the PEELI training comprises of ten days. It seemed less to trainees. It seems less time to trainees, so it is suggested to plan the training duration for more than 10 days to satisfy the needs of the participants.

\section{Lack of coordination}

It is observed and analyzed from the interview that is no proper communication between the British-Council trainers and the trainees is carried out. It will be helpful, if both master trainer and the trainees coordinate and communicate with each other after the training to satisfy the learner's queries and confusions.

\section{Practicality}

The trainings must include practical implementation of their learning and information in their respective schools. That way not only the other teachers and students get benefit but the leaner also applies their learned skills to polish and develop more confidence. 


\section{Advertisement}

Proper advertisement should be carried out to attract the government teachers to apply for the PEELI training. This can be done by banners, pamphlets and through PEELI trainees to conduct in-service workshops.

\section{Training Manual}

The training manual which are part of the most British Council's workshops, must be given at the venue of the PEELI training for smooth flow and to learn about the schedules (Karim et al., 2019). It should carry a complete package of the whole schedule of the training with the introduction to the master trainer. It seems more professional and helpful.

\section{More Similar Workshops}

More similar workshops, must be planned in the future to enhance and refine the government teachers' knowledge, language, professional and pedagogical skills. Like many other on the list, more has to be add on for the betterment of education and language so that all the fields excel as education is the base for every profession in the world.

To wrap up, it can confidently say that this training makes the teachers more confident. However, different incentives given during the training for example participation certificates will make it more attractive and teachers will be more motivated (La Duke, 2017). The trainees confidently recommend it for the other teachers thus giving a new dimension to their teaching and learning. Most importantly, their English language skills have been improved to some extent. It is a result oriented and well-planned training. However, it can be made more interactive by considering the recommendations for future endeavors. Nevertheless, the trainees highly recommend it for the other teachers to apply and attend this training, which makes it a successful event, altogether

\section{References}

Ahmad, S., \& Yousaf, M. (2011). Special education in Pakistan: In the perspectives of educational policies and plans. Academic Research International, 1(2), 228-241.

Akram, M., \& Mahmood, A. (2007). The status and teaching of English in Pakistan. Language in India, 7(12), 1-7.

Ali, M. Q., Nazir, Y., Shaheen, R., \& Burki, A. N. (2016). Effectiveness of mentoring indicators in primary school teachers' evaluation toward professional development. studies, 4 , 661-679.

Ammar, A., Naveen, A. L. I., Fawad, A., \& Qasim, K. (2015). Language policy and medium of instruction issue in Pakistan. Acta Linguistica Asiatica, 5(1), 111-124.

Armat, M. R., Assarroudi, A., Rad, M., Sharifi, H., \& Heydari, A. (2018). Inductive and deductive: Ambiguous labels in qualitative content analysis. The Qualitative Report, 23(1), 219-221.

Barash, Y., Guralnik, G., Tau, N., Soffer, S., Levy, T., Shimon, O., ... \& Klang, E. (2020). Comparison of deep learning models for natural language processing-based classification of non-English head CT reports. Neuroradiology, 62(10), 1247-1256.

Barrichello, A., Morano, R. S., Feldmann, P. R., \& Jacomossi, R. R. (2020). The importance of education in the context of innovation and competitiveness of nations. International Journal of Education Economics and Development, 11(2), 204-224.

Bashir, S. O. H. A., \& Batool, F. I. Z. Z. A. (2017). English as medium of instruction in Punjab: The 2009 experiment. Lahore Journal of Policy Studies, 7(1), 13-45. 
Bashiruddin, A., \& Qayyum, R. (2014). Teachers of English in Pakistan: Profile and recommendations. NUML Journal of Critical Inquiry, 12(1), 1-19.

Bell, E., Bryman, A., \& Harley, B. (2018). Business research methods. Oxford university press. Bloomfield, J., \& Fisher, M. J. (2019). Quantitative research design. Journal of the Australasian Rehabilitation Nurses Association, 22(2), 27-30.

Buckley, P. J., Doh, J. P., \& Benischke, M. H. (2017). Towards a renaissance in international business research? Big questions, grand challenges, and the future of IB scholarship. Journal of International Business Studies, 48(9), 1045-1064.

Ciraso, A. (2012). An evaluation of the effectiveness of teacher training: some results from a study on the transfer factors of teacher training in Barcelona area. Procedia-Social and Behavioral Sciences, 46, 1776-1780.

Fareed, M., Jawed, S., \& Awan, S. (2018). Teaching English language at SSC level in private non-elite schools in Pakistan: Practices and problems. Journal of Education and Educational Development, 5(1), 80-95.

Habib, M. (2013). Education in Pakistan's Punjab: Outcomes and Interventions. Lahore Journal of Economics, 18, 21-48.

Haidar, S. (2018). The role of English in developing countries: English is a passport to privilege and needed for survival in Pakistan. English Today, 35(3), 42-48.

Haidar, S., \& Fang, F. (2019). English language in education and globalization: A comparative analysis of the role of English in Pakistan and China. Asia Pacific Journal of Education, 39(2), 165-176.

Hameed-ur-Rehman, M., \& Sewani, S. M. S. (2013). Critical analysis of the educational policies of Pakistan. The Dialogue, 8(3), 247-260.

Hassan, S., \& Ahmed, M. (2015). Issues of English language learners in communication at intermediate level in Pakistan. Journal of Literature, Languages and Linguistics, 8, 104111.

Hooshyar, D., Kori, K., Pedaste, M., \& Bardone, E. (2019). The potential of open learner models to promote active thinking by enhancing self-regulated learning in online higher education learning environments. British Journal of Educational Technology, 50(5), 2365-2386.

Imtiaz, S. H. A. H. I. D. (2014). Exploring strategies for English language teaching of Pakistani students in public sector colleges. Research Journal of English Language and Literature, 2(2), 247-253.

Karim, A., Ahmed, Z., Shahed, F. H., Rahman, M. M., \& Mohamed, A. R. (2019). Challenges affecting the implementation off 50 million in-Service training programs for English teachers in Bangladesh. The Qualitative Report, 24(10), 2457-2485.

Khan, T. J., \& Khan, N. (2016). Obstacles in learning English as a second language among intermediate students of districts Mianwali and Bhakkar, Pakistan. Open Journal of Social Sciences, 4(02), 154-162.

La Duke, P. (2017). How to evaluate training: using the kirkpatrick model. Professional safety, 62(8), 20-33.

Malik, A. A. (2015). Identification of the factors of quality teacher training and development of a model program in Pakistan. VFAST Transactions on Education and Social Sciences, 5(2), 11-25.

Manan, S. A., David, M. K., \& Dumanig, F. P. (2016). English language teaching in Pakistan: Language policies, delusions and solutions. English language education policy in Asia, 28(2), 219-244. 
McKay, A. S., Karwowski, M., \& Kaufman, J. C. (2017). Measuring the muses: validating the Kaufman domains of creativity scale (K-DOCS). Psychology of Aesthetics, Creativity, and the Arts, 11(2), 216.

Mohammad, N., Masum, R., Ali, Z., \& Baksh, K. (2018). Teaching practices of English language in the schools of Lasbela District, Pakistan. International Journal of Experiential Learning \& Case Studies, 2(2), 34-39.

Nadeem, H. A., Saadi, A. M., Fatima, N., \& Sahar, N. E. (2020). PEELI Training and Professional Development of Primary School Teachers. Advance Social Science \& Humanities, 12(2), 178-191.

Naz, S., Jabeen, S., \& Rashid, A. (2020). Evaluation of Punjab Education and English Language Initiative (PEELI) Project in Pakistan. Global Regional Review, 5(1), 332-339.

Nusrat, S. (2015). Challenges of monitoring and evaluating large scale teacher education projects: PEELI. Ensuring Quality in English Language Teacher Education, 79, 109-123.

Pérez-Ordás, R., Nuviala, A., Grao-Cruces, A., \& Fernández-Martínez, A. (2021). Implementing Service-Learning Programs in Physical Education; Teacher Education as Teaching and Learning Models for All the Agents Involved: A Systematic Review. International Journal of Environmental Research and Public Health, 18(2), 669.

Rafique, N., Sultan, B., Ahmad, S., \& Imran, M. (2018). Teachers' Role in Implementation of English Language Teaching Policies in Public Primary Schools of Rural Area in Punjab, Pakistan. Language in India, 18(4), 252-260.

Rahman, T. (1998). Language-teaching policies in Pakistan. Islamabad, Pakistan: Sustainable Development Policy Institute.

Rashid, S., Cunningham, U., \& Watson, K. (2017). Task-based language teaching with smartphones: A case study in Pakistan. Teachers and Curriculum, 17(2), 33-40.

Reio, T. G., Rocco, T. S., Smith, D. H., \& Chang, E. (2017). A critique of Kirkpatrick's evaluation model. New Horizons in Adult Education and Human Resource Development, 29(2), 35-53.

Saeed, A., \& Zubair, S. (2019). Making sense of public-private partnership: a case of Punjab education foundation. Journal of Public Value and Administrative Insight, 2(4), 6-13.

Smith, W. C., Fraser, P., Chykina, V., Ikoma, S., Levitan, J., Liu, J., \& Mahfouz, J. (2017). Global citizenship and the importance of education in a globally integrated world. Globalisation, Societies and Education, 15(5), 648-665.

Soudien, C. (Ed.). (2017). Nelson Mandela: Comparative perspectives of his significance for education. Springer.

Souza, A. C. D., Alexandre, N. M. C., \& Guirardello, E. D. B. (2017). Psychometric properties in instruments evaluation of reliability and validity. Epidemiologia e Serviços de Saúde, 26, 649-659.

Teevno, R. A. (2011). Challenges in teaching and learning of English at secondary level class X. International Journal of Human Resource Studies, 1(2), 27-43.

Thomas, M. (2013). Teachers' beliefs about classroom teaching-Teachers' knowledge and teaching approaches. Procedia-Social and Behavioral Sciences, 89, 31-39.

Warsi, J. (2004). Conditions under which English is taught in Pakistan: An applied linguistic perspective. Sarid Journal, 1(1), 1-9.

Zakaria, M., Janjua, S. Y., \& Fida, B. A. (2016). Internationalization of Higher Education: Trends and Policies in Pakistan. Bulletin of Education and Research, 38(1), 75-88. 